\title{
Nuwe Fe(III) Schiff-basis ONO-ligand komplekse wat bestudeer is vir die katalise van organiese reaksies
}

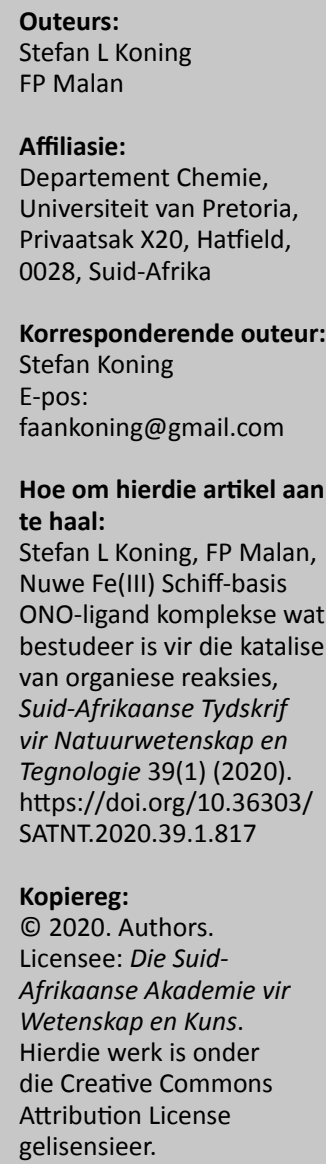

Korresponderende outeur: Stefan Koning

\begin{abstract}
Novel Fe(III) Schiff base ONO-ligand complexes studied for the catalysis of organic reactions: Six novel Fe(III) complexes were synthesised to use them as catalysts for organic reactions. Catalysis was tested for carbonyl-olefin metathesis, [2 $\pi+2 \pi]$ cycloaddition, phenylacetylene trimerization, formic acid dehydrogenation and transfer hydrogenation. No catalytic activity was shown towards any of these reactions. Electrochemical studies reveal why this was the case.
\end{abstract}

Organiese chemie is ' $n$ belangrike veld in die industrie en is gefokus op die sintese van koolwaterstowwe. Hierdie belangrike klas van molekules staan sentraal in die farmaseutiese en petroleumindustrie. Daar is 'n groot aantal reaksies op hierdie gebied wat afhanklik is van die gebruik van katalisators. Sommige van hierdie katalisators is gebaseer op skaars en dus duur metale soos rutenium en nikkel. Indien hierdie katalisators dus vervang wil word deur nuwes met soortgelyke kenmerke teen 'n laer prys, sal die eerste plek om te soek in dieselfde groep op die periodieke tabel wees - maar dan 'n metaal wat oorvloedig beskikbaar is. Dit vestig ons aandag dus op yster wat in dieselfde groep as rutenium lê.

Hierdie studie het spesifiek die katalise van die karboniel-olefien metatese (KOM) reaksie ondersoek. Hierdie einste reaksie is in 'n onlangse artikel van Ludwig et al (2016) nagevors. Daar is gevind dat metaalgebaseerde Lewis-sure uitstekende katalitiese toepassing op KOMreaksies het. Hulle het spesifiek bewys dat $\mathrm{FeCl}_{3}$ ('n Fe(III)-verbinding) die intramolekulêre KOM-reaksie van 'n wye reeks substrate kon kataliseer.

Met hierdie kennis van die vermoë van 'n eenvoudige Fe(III)-verbinding om karboniel-olefien metatese reaksies te kataliseer, het $\mathrm{Fe}$ (III) beslis die potensiaal om 'n uiters nuttige soort transformasie met talle toepassings te ontsluit. Ondanks hierdie feit, is al die moontlikhede en onsekerhede daarvan nog nie ten volle verken soos met die olefien-olefien metatese reaksie nie. Laasgenoemde is tans een van die kragtigste reaksies om koolstof-koolstofbindings te vorm. Hierdie kennis is aanloklik om die werklike potensiaal van die karboniel-alkeen-analoog te ondersoek en te bevorder. Katalisatorontwikkeling is dus nodig.

Vir hierdie projek is die genoemde KOM-reaksie op sitronellaal gepoog, tesame met 'n ringsluitende sikloaddisie-reaksie van diallylamien, trimerisasie van fenielasetileen, die katalise van mieresuur-dehidrogenering en oordrag hidrogenering op bensofenoon. In plaas van $\mathrm{FeCl}_{3}$ as katalisator is daar 'n reeks nuwe Fe(III)-komplekse gesintetiseer en getoets vir katalitiese aktiwiteit. Hierdie komplekse is kombinasies van die ONO-tridentate ligand, bidentate asetielacetonato en wisselende enkel ligande.

Helaas is bevestig dat die komplekse wat getoets is nie in enige van die bogenoemde reaksies as katalisator kon dien nie. Om 'n beter begrip te kry waarom daar geen aktiwiteit gevind is nie, is sikliese voltammetrie-studies gedoen wat bevind het dat die komplekse nie redoksomkeerbaar is nie en dus dat die ligande nie toelaat dat die komplekse redoksaktief is nie. Dit is uiteraard ' $n$ vereiste dat ' $n$ kompleks redoksaktief is om as 'n effektiewe katalisator te dien. Hierdie studie dien dus as rigtingaanwyser vir toekomstige studies met 'n soortgelyke tema.

\section{Verwysings}

Ludwig JR, Zimmerman PM, Gianino JB, Schindler CS. 2016. Iron (III)-catalysed carbonyl-olefin metathesis. Nature 533(7603), 374379.

Nota: 'n Seleksie van referaatopsommings: Studentesimposium in die Natuurwetenskappe, 31 Oktober - 1 November 2019 , Universiteit van die Vrystaat. Reëlingskomitee: Prof Rudi Pretorius (Departement Geografie, Universiteit van Suid-Afrika); Dr Hertzog Bisset (Suid-Afrikaanse Kernenergie-korporasie; Dr Ernie Langner (Departement Chemie, Universiteit van die Vrystaat) en Dr Wynand Nel (Departement Rekenaarwetenskap en Informatika, Universiteit van die Vrystaat). 